\title{
ANALISA PERUBAHAN GARIS PANTAI MENGGUNAKAN TEKNOLOGI PENGINDERAAN JAUH DI WILAYAH PESISIR KECAMATAN LAKUDO KABUPATEN BUTON TENGAH
}

\section{Analysis of Changes in Coast Line Using Remote Sensing Technology in Coastal Area of Lakudo District Central Buton Regency}

\author{
Nurbiah $^{1}$, La Ode Muh. Yasir Haya ${ }^{2}$, dan A. Ginong Pratikino ${ }^{3}$ \\ ${ }^{1}$ Mahasiswa Jurusan Ilmu Kelautan, \\ Fakultas Perikanan dan Ilmu Kelautan, Universitas Halu Oleo. \\ Jl. H.E.A Mokodompit Kampus Hijau Bumi Tridharma Anduonohu Kendari 93232, Telp/Fax: (0401) 3193782 \\ ${ }^{2}$ Surel: lmyasir.haya@gmail.com \\ ${ }^{3}$ Surel: asringinong@gmail.com
}

\begin{abstract}
Abstrak
Garis pantai adalah garis batas pertemuan antara daratan dan air laut, dimana posisinya tidak tetap dan dapat berpindah sesuai dengan pasang surut air laut dan erosi pantai. Penelitian ini bertujuan untuk mengestimasi perubahan garis pantai dan mengestimasi laju perubahan garis pantai menggunakan data Citra dari Tahun 1998-2018 di Wilayah Pesisir Kecamatan Lakudo, Kabupaten Buton Tengah. Penelitian ini dilaksanakan pada bulan Januari-Mei Tahun 2019. Metode yang digunakan dalam penelitian ini adalah metode Overlay (tumpang susun) antara Citra Landsat 5 TM Tahun 1998, Citra Landsat 7 +ETM Tahun 2001 dan 2010 dan Citra Landsat 8 OLI Tahun 2018. Hasil penelitian menunjukkan bahwa selama 20 tahun perubahan garis pantai yang terjadi di lokasi peneltian berupa abrasi dan akresi. Perubahan garis pantai berupa abrasi berkisar antara 11-156 m terjadi di Desa Lolibu, Wajogu, Moko, Mone, Teluk Lasongko, Matawine, Wongko Lakudo, Lakudo, Gu Timur, Nepa Mekar, Boneoge, Waara dan One Waara. Sedangkan akresi berkisar antara 10-102 m terjadi di Desa Lolibu, Moko, Mone, Teluk Lasongko, Wongko Lakudo, Lakudo, Gu Timur, Nepa Mekar, Boneoge, Mandongka, Waara dan One Waara. Laju perubahan garis pantai berupa abrasi berkisar antara 0.55-7.80 m/thn sedangkan akresi berkisar antara 0.50-5.10 m/thn. Perubahan tersebut utamanya disebabkan oleh faktor hidro-oseanografi yakni arus, pasut dan gelombang serta faktor antropogenik yakni pembangunan pemukiman, penambangan pasir dan degradasi hutan mangrove.
\end{abstract}

Kata Kunci: Perubahan Garis Pantai, Citra Landsat, Kecamatan Lakudo

\begin{abstract}
The coastline is the boundary line between the land and sea water, where the position is not fixed and can move according to the tides and coastal erosion. This study aims to estimate shoreline changes and estimate the rate of shoreline change using Citra data from 1998-2018 in the Coastal Area of Lakudo District, Central Buton Regency. This research was conducted in January-May of 2019. The method used in this study is the Overlay method between 1998 Landsat 5 TM Imagery, Landsat 7 + ETM Imagery in 2001 and 2010 and OLI Landsat 8 Imagery in 2018. which occurred at the research site in the form of abrasion and accretion. Changes in coastline in the form of abrasion ranged from 11-156 m occurred in Lolibu, Wajogu, Moko, Mone, Teluk Lasongko , Matawine, Wongko Lakudo, Lakudo, Gu Timur, Nepa Mekar, Boneoge, Waara and One Waara. Whereas accretion ranged from 10-102 m occurred in Lolibu, Moko, Mone, Lasongko Bay, Wongko Lakudo, Lakudo, Gu Timur, Nepa Mekar, Boneoge, Mandongka, Waara and One Waara. The rate of shoreline change in the form of abrasion ranges from $0.55-7.80 \mathrm{~m} / \mathrm{thn}$ while accretion ranges from $0.50-5.10 \mathrm{~m} / \mathrm{thn}$. These changes are mainly caused by hydro-oceanographic factors namely currents, tides and waves and anthropogenic factors, namely the construction of settlements, sand mining and degradation of mangrove forests.
\end{abstract}

Keywords: Coastline Change, Landsat Image, Lakudo District.

\section{Pendahuluan}

Wilayah pesisir merupakan wilayah yang sangat rentan terhadap perubahan baik yang berasal dari darat maupun dari laut. Apabila ditinjau dari garis pantai maka wilayah pesisir mempunyai dua macam batas yaitu batas yang sejajar dengan garis pantai dan batas yang tegak lurus dengan garis pantai. Menurut Pahala dan Heni (2007), Lingkungan pantai adalah daerah yang selalu mengalami perubahan karena daerah tersebut menjadi tempat pertemuan dua energi yaitu yang berasal dari lautan dan daratan. Perubahan lingkungan dapat terjadi baik secara lambat maupun sangat cepat, tergantung pada keseimbangan kondisi antara topografi, batuan atau sedimen dan sifat-sifatnya terhadap gelombang, pasang surut dan angin. Menurut Arief et al., (2011) perubahan garis pantai adalah satu proses tanpa henti (terus 
menerus) melalui berbagai proses alam yaitu pergerakan sedimen, arus susur pantai (Longshore current) dan gelombang.

Garis pantai adalah garis batas pertemuan antara daratan dan air laut, dimana posisinya tidak tetap dan dapat berpindah sesuai dengan pasang surut air laut dan erosi pantai (Shuhendry, 2004). Perubahan garis pantai di pengaruhi oleh beberapa faktor yaitu faktor hidrooseanografi dan antropogenik. Faktor hidro-oseanografi seperti gelombang, arus dan pasut, sedangkan faktor antropogenik disebabkan oleh aktivitas manusia seperti pemanfaatan mangrove sebagai kayu bakar dan tambak serta penambangan pasir.

Perairan Kecamatan Lakudo, Kabupaten Buton Tengah merupakan daerah yang dijadikan berbagai tempat kegiatan dan aktivitas manusia yang dapat menunjang perekonomian masyarakat setempat seperti sebagai tempat penangkapan ikan, tempat wisata, pembangunan dermaga, penambangan pasir serta sebagai akses tempat penyebrangan ke pulau Buton (kota Bau-Bau). Banyaknya kegiatan dan aktivitas yang dilakukan diperairan tersebut dapat mempengaruhi kondisi hidro-oseanografi. Sehingga dapat menimbulkan dampak negatif seperti terjadinya perubahan garis pantai pada Wilayah Pesisir Kecamatan Lakudo Kabupaten Buton Tengah.

Pemantauan perubahan garis pantai telah dilakukan dengan menggunakan teknologi penginderaan jauh. Hal ini sesuai dengan pernyataan Iwan (2015) bahwa, perubahan garis pantai dengan menggunakan teknologi penginderaan jauh salah satu metode observasi yang dapat dilakukan secara multi-temporal karena ketersediaan data yang cukup melimpah dan mudah diakses. Untuk melihat perubahan garis pantai dan material pantai dibutuhkan data yang dapat diperoleh secara periodik dengan perkembangan teknologi penginderaan jauh yang sangat pesat, terutama citra satelit. Citra satelit mampu mendukung tersedianya data karakteristik suatu wilayah dalam waktu yang relatif singkat dan cakupan wilayah yang luas, sehingga dapat memberikan informasi yang dibutuhkan untuk pemantauan dan penelitian salah satunya yaitu pemantauan perubahan garis pantai.

\section{Bahan Dan Metode}

Penelitian ini dilaksanakan pada Bulan Januari-Juni Tahun 2019. Bertempat di wilayah pesisir Kecamatan Lakudo, Kabupaten Buton Tengah. $\quad\left( \pm 176,87 \mathrm{~km}^{2}\right)$ dengan posisi $05^{\circ} 17^{\prime} 53,92^{\prime \prime}-05^{\circ} 25^{\prime} 19,18^{\prime \prime}$ LS dan $122^{\circ} 28^{\prime} 55,12^{\prime \prime}-122^{\circ} 35^{\prime} 41,78^{\prime \prime}$ BT. Lokasi penelitian ini dapat dilihat pada Gambar 1.

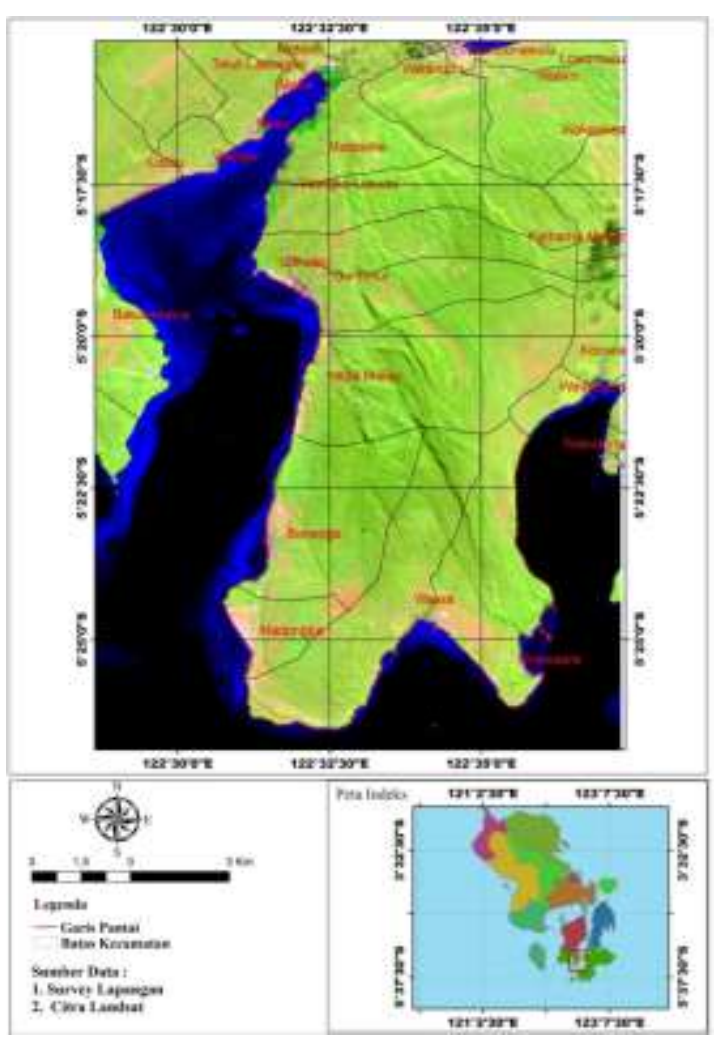

Gambar 1. Peta Lokasi Penelitian

Kegiatan penelitian ini memiliki beberapa tahapan yaitu : pengumpulan data, pengolahan data citra awal, koreksi pasang surut terhadap citra, koreksi garis pantai menggunakan metode Overlay (tumpang susun) setiap citra satelit Landsat. Berikut adalah diagram alir pikir penelitian yang dapat dilihat pada Gambar 2. 


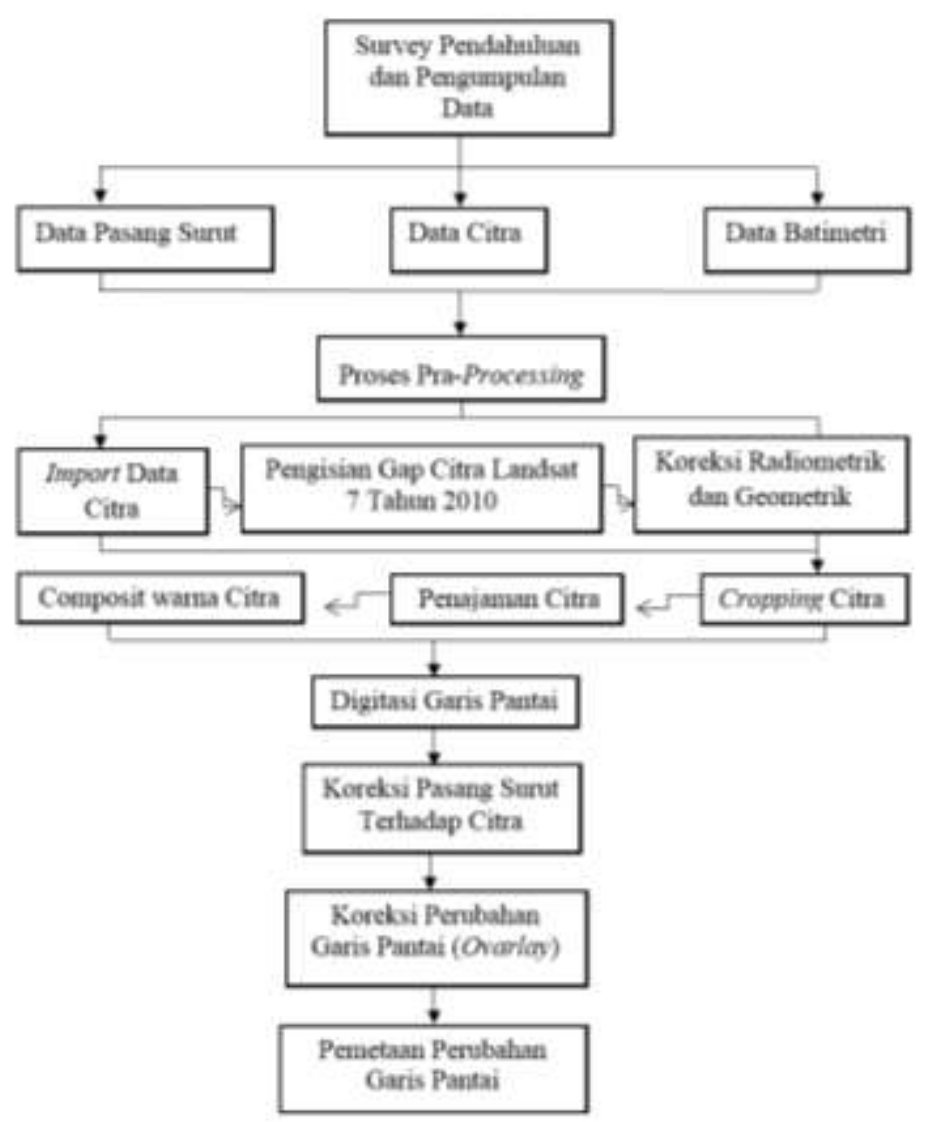

Gambar 2. Diagram Alir Penelitian di Wilayah Pesisir Kecamatan Lakudo

Tabel 1. Alat dan Bahan yang Digunakan pada Penelitian

\begin{tabular}{cll}
\hline No & \multicolumn{1}{c}{ Alat dan Data } & \multicolumn{1}{c}{ Kegunaan } \\
\hline 1 & Alat & Untuk menentukan titik koordinat/posisi \\
& - GPS map 67CSx & Untuk mendokumentasi lokasi penelitian \\
& - Kamera & Untuk mengolah citra satelit \\
& - Software Er mapper 7.0 & Untuk mendigitasi citra satelit \\
& - Software ArcGis 10.3 & Untuk menghitung MSL \\
& - Software Pasut BPPT & \\
& - Software GapFill & Untuk mengisi gap citra satelit Tahun 2010 \\
& & \\
& Bahan & \\
& - Data Citra Landsat 5 TM tanggal & Untuk mengetahui perubahan garis pantai \\
& 10 Agustus Tahun 1998 Path 112 & \\
& Row & \\
- Data Citra Landsat 7 +ETM & Untuk mengetahui perubahan garis pantai \\
& tanggal 29 Oktober Tahun 2001 & \\
& dan 10 September Tahun 2010 & \\
& Path 112 Row 64 & \\
- Data Citra Landsat 8 OLI/TIRS 14 & Untuk mengetahui perubahan garis pantai \\
& Juni Tahun 2018 Path 112 Row 64 & \\
- Data Pasut (Dihidros TNI AL) & Untuk mengoreksi pasang surut terhadap \\
- Data Batimetri (Dihidros TNI AL) & perubahan garis pantai
\end{tabular}

\section{Hasil Dan Pembahasan}


Koreksi perubahan garis pantai di Kecamatan Lakudo, Kabupaten Buton Tengah adalah dengan menggunakan metode overlay (tumpang susun). Metode overlay merupakan metode penyatuan data yang berbeda. Semua data citra landsat yang telah dikoreksi dengan data pasang surut yang kemudian di overlay untuk mengetahui perubahan garis pantai yang terjadi selama 20 tahun (1998-2018) dengan menggunakan perangkat lunak ArcGIS 10.3. Overlay garis pantai pada Citra Landsat Tahun 1998 dan 2018 dilihat pada Gambar 3.

Berdasarkan hasil interpretasi Citra Landsat Tahun 1998 (Gambar 3) wilayah Pesisir Kecamatan Lakudo, Kabupaten Buton Tengah masih banyak memiliki mangrove dan masih kurang pemanfaatan alih fungsi lahan sebagai tempat wisata, pembangunan dermaga/pelabuhan dan pemukiman masyarakat disekitar pantai jika dibandingkan dengan Citra Landsat Tahun 2001, 2010 dan 2018. Hal tersebut didukung oleh Arpakul et al., (2017) bahwa, wilayah Kecamatan Mawasangka, Kabupaten Buton Tengah masih banyak memiliki mangrove dan masih sedikit permukiman, masih kurang adanya pemanfaatan alih fungsi lahan sebagai tempat wisata, pelabuhan/dermaga dan penambangan pasir, dan pembuatan bangunan pelindung pantai yang ada di sekitar pantai. Hal ini berdasarkan data jumlah penduduk tahun 1995 pada wilayah Kecamatan Mawasangka adalah kurang lebih 9.174 jiwa (PPSP, 2014).

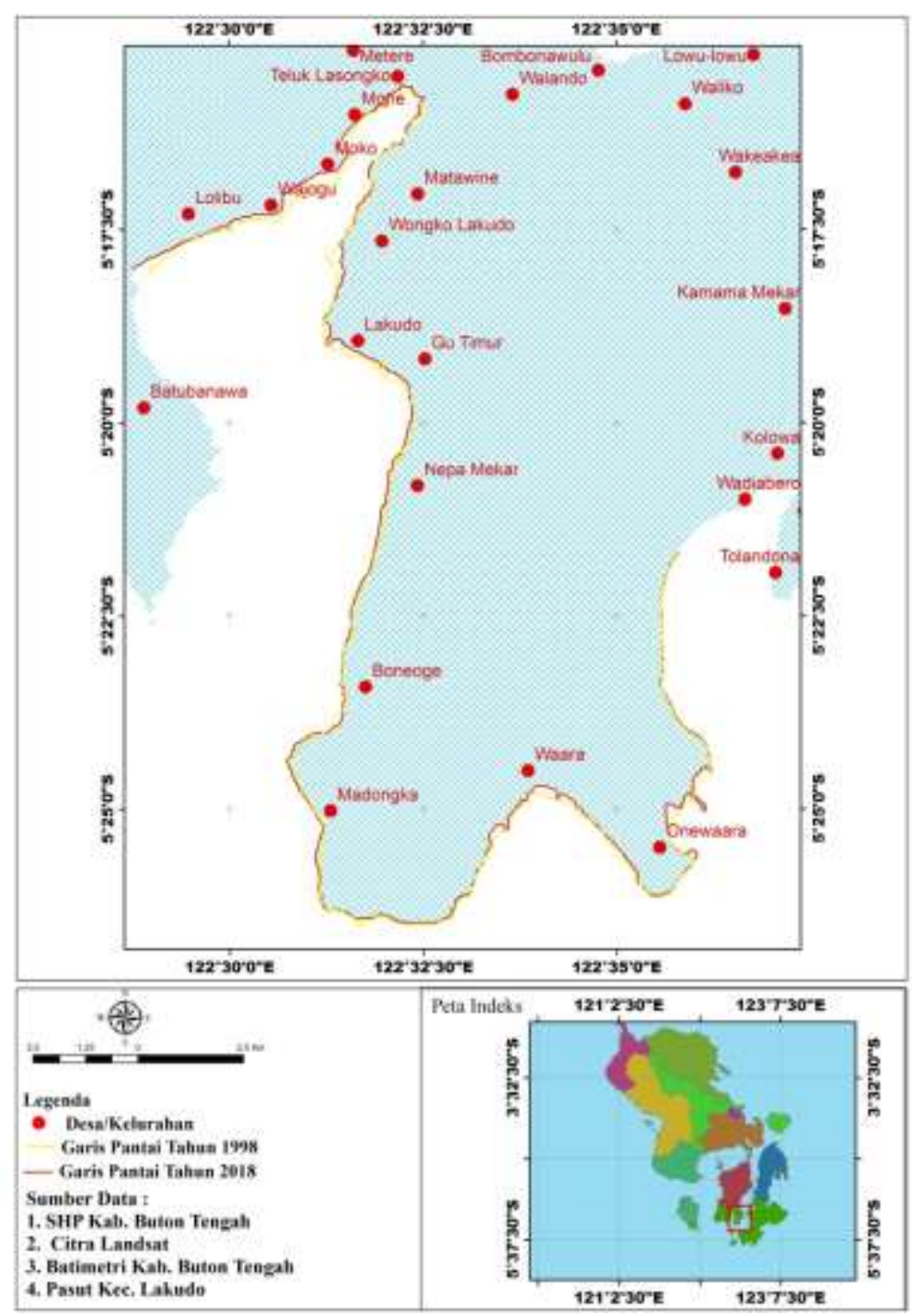

Gambar 3. Overlay garis pantai pada Citra Landsat Tahun 1998 dan 2018 
Berdasarkan hasil interprestasi (Gambar 3) Citra Landsat Tahun 2018 di wilayah Pesisir Kecamatan Lakudo, Kabupaten Buton Tengah dapat dilihat bahwa semakin berkurangnya mangrove karena banyaknya masyarakat yang memanfaatkan mangrove sebagai kayu bakar, pemanfaatan alih fungsi lahan sebagai pembangunan dermaga/pelabuhan, penambangan pasir dan semakin banyaknya pemukiman masyarakat yang ada disekitar pantai. Berdasarkan pengamatan di lokasi peneltian kondisi tersebut menajdi salah satu faktor penyebab terjadinya perubahan garis pantai disepanjang pantai lokasi penelitian. Selain itu, perubahan garis pantai yang terjadi dari Tahun 19982018 di duga disebabkan oleh topografi pantai di Kecamatan Lakudo yang landai sehingga material-material yang ada disekitar daerah pemukiman akan terbawa ke laut oleh arus pada saat musim hujan. Hal tersebut didukung dengan pernyataan Halim et al., (2014) dalam penelitiannya bahwa, adanya pemanfaatan pemukiman yang semakin banyak di sekitar pantai, adanya beberapa pelabuhan berbentuk groin dan adanya dinding pelindung pantai (revetment) yang dapat mempengaruhi pola pergeseran arus yang berfungsi sebagai agen penyebaran sedimen di sekitar pantai. Hal ini juga didukung oleh penelitian Ayu (2015) bahwa, Aktifitas manusia yang memanfaatkan pantai untuk berbagai kepentingan, dapat merubah morfologi atau bahkan merusak lingkungan dikawasan pantai.

Selian itu, Kalay et al., (2011) tentang hasil penelitiannya, mengenai perubahan garis pantai disepanjang pantai indramayu yang menyatakan bahwa, perbedaan nilai pemunduran pada pantai Teluk Indramayu diduga disebabkan oleh perbedaan karakteristik pantai. Secara Umum, kondisi pantai Teluk Indramayu sangat terbuka terhadap dinamika perairan sebagai akibat dari hilangnya mangrove yang menjadi pelindung pantai.

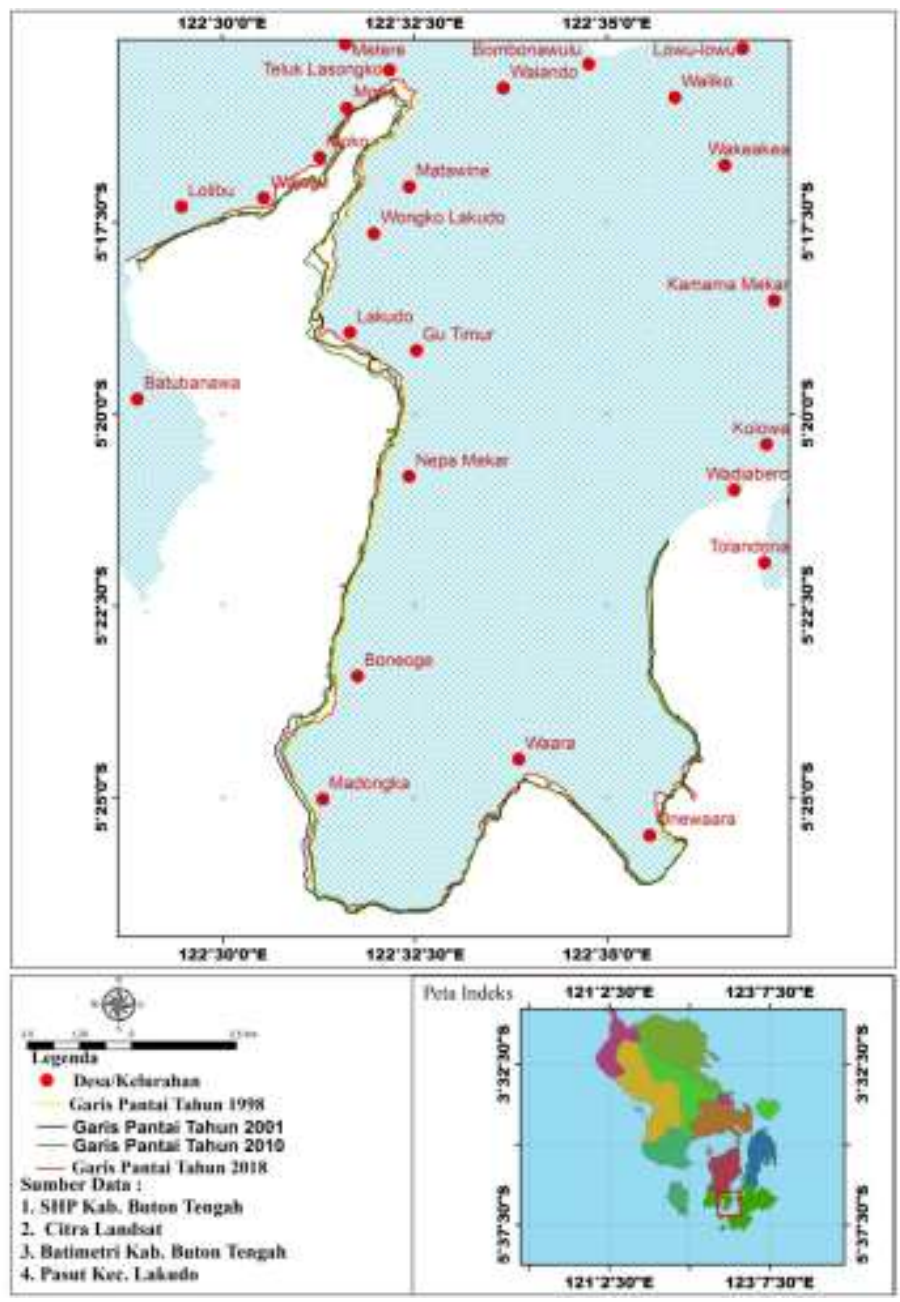

Gambar 4. Overlay garis pantai pada citra landsat tahun 1998, 2001, 2010 dan 2018. 
Perubahan garis pantai yang terjadi di wilayah Pesisir Kecamatan Lakudo, Kabupaten Buton Tengah, sama dengan penelitian yang dilakukan Arpakul et al., (2017) dengan judul, Studi Perubahan Garis Pantai dengan Pendekatan Penginderaan Jauh di Wilayah Pesisir Kecamatan Mawasangka, Kabupaten Buton Tengah metode yang digunakan adalah overlay Citra Landsat Tahun 1995 dan 2015, dan Halim et al., (2016) dengan Judul, Studi Perubahan Garis Pantai dengan Pendekatan Penginderaan Jauh di Wilayah Pesisir Kecamatan Soropia. Metode yang digunakan adalah overlay Citra Landsat Tahun 1990, Tahun 2001 dan Tahun 2014.

Hasil tumpang-susun (Overlay) data citra yaitu Citra Landsat Tahun 1998, 2001, 2010 dan Tahun 2018. Garis pantai Tahun 1998 digunakan sebagai garis pantai awal untuk melihat seberapa besar jarak perubahan garis pantai yang terjadi selama 20 tahun seperti disajikan pada (Gambar 4). Dari gambar tersebut dapat disimpulkan bahwa disepanjang pantai wilayah Pesisir Kecamatan Lakudo, Kabupaten Buton Tengah telah mengalami perubahan garis pantai ditunjukkan dengan adanya abrasi maupun akresi. Hal tersebut didukung oleh Lubis et al., (2012) dalam penelitiannya bahwa, hasil interpretasi yang dilakukan terhadap Citra Landsat di kawasan Pesisir Pantai Kecamatan Talawi, kemudian masing-masing hasil interpretasi tersebut di tumpang-tindihkan (Overlay) sehingga menghasilkan beberapa garis pantai yang saling-silang. Hasil tersebut kemudian di pilah dan dikelompokan menjadi pe-rubahan bersifat abrasi atau perubahan bersifat akresi. Selain itu, hasil peneltian Jaya et al., (2017) menyatakan, identifikasi perubahan garis pantai dilakukan dengan analisis tumpang susun antara Citra Landsat TM Tahun 1995, Landsat TM Tahun 2005, dan Landsat OLI Tahun 2015. Perubahan garis pantai yang terjadi di kabupaten Gianyar cenderung mengalami abrasi atau pengikisan material pantai.

Berdasarkan hasil interpretasi citra (Gambar 4) dari Tahun 1998-2018 memperlihatkan bahwa perubahan garis pantai yang terjadi di wilayah Pesisir Kecamatan Lakudo, Kabupaten Buton Tengah lebih dominan terjadinya abrasi (pengurangan daratan) jika dibandingkan dengan akresi (penambahan daratan). Hal ini ditunjukkan dengan mundurnya garis pantai pada daerah tersebut. Perubahan garis pantai mulai terjadi pada Tahun 2001 hingga Tahun 2018. Seperti yang telah dijelaskan sebelumnya bahwa peneliti menggunakan Citra Landsat Tahun 1998 sebagai patokan/acuan untuk mengetahui perubahan garis pantai yang terjadi selama 20 Tahun. Hal tersebut didukung oleh penelitian Arpakul et al., (2017) dalam penelitiannya bahwa, perubahan garis pantai yang terjadi di Wilayah Pesisir Kecamatan Mawasangka lebih dominan terjadinya akersi, sehingga jarak pergeseran garis pantai lebih sedikit dibandingkan dengan abrasi.

Tabel 2. Bentuk perubahan garis pantai berupa abrasi di Kecamatan Lakudo, Kabupaten Buton Tengah pada setiap desa/kelurahan pada Tahun 1998-2018.

\begin{tabular}{|c|c|c|c|}
\hline \multirow{3}{*}{$\begin{array}{c}\text { Desa/Kelurahan } \\
\text { Di Kecamatan } \\
\text { Lakudo }\end{array}$} & \multirow{3}{*}{$\begin{array}{c}\text { Perubahan } \\
\text { Garis Pantai } \\
\text { 1998-2018 }\end{array}$} & \multicolumn{2}{|c|}{ Titik Koordinat Geografi } \\
\hline & & \multicolumn{2}{|c|}{ Abrasi } \\
\hline & & $\mathbf{X}$ & $\mathbf{Y}$ \\
\hline D. Lolibu & Abrasi & $122^{0} 29^{\prime} 7,81^{\prime \prime}$ & $05^{0} 17^{\prime} 51,58^{\prime \prime}$ \\
\hline D. Wajogu & Abrasi & $122^{0} 30^{\prime} 59,02^{\prime \prime}$ & $05^{0} 16^{\prime} 57,51^{\prime \prime}$ \\
\hline D. Moko & Abrasi & $122^{0} 31^{\prime} 48,07^{\prime \prime}$ & $05^{0} 16^{\prime} 48,18^{\prime \prime}$ \\
\hline D. Mone & Abrasi & $122^{0} 31^{\prime} 48,91^{\prime \prime}$ & $05^{0} 15^{\prime} 47,21^{\prime \prime}$ \\
\hline D. Teluk Lasongko & Abrasi & $122^{0} 32^{\prime} 13,17^{\prime \prime}$ & $05^{0} 15^{\prime} 43,76^{\prime \prime}$ \\
\hline D. Matawine & Abrasi & $122^{0} 31^{\prime} 46,86^{\prime \prime}$ & $05^{0} 17^{\prime} 19,29^{\prime \prime}$ \\
\hline D. Wongko Lakudo & Abrasi & $122^{0} 31^{\prime} 24,28^{\prime \prime}$ & $05^{0} 18^{\prime} 0,85^{\prime}$, \\
\hline Kel. Lakudo & Abrasi & $122^{0} 31^{\prime} 30,32^{\prime \prime}$ & $05^{0} 19^{\prime} 4,60^{\prime \prime}$ \\
\hline Kel. Gu Timur & Abrasi & $122^{0} 32^{\prime} 7,90^{\prime}$, & $05^{0} 19^{\prime} 25,92^{\prime \prime}$ \\
\hline D. Nepa Mekar & Abrasi & $122^{0} 32^{\prime} 11,92^{\prime \prime}$ & $05^{0} 20^{\prime} 21,90^{\prime \prime}$ \\
\hline Kel. Boneoge & Abrasi & $122^{0} 31^{\prime} 26,06^{\prime \prime}$ & $05^{0} 23^{\prime} 25,35^{\prime \prime}$ \\
\hline D. Mandongka & - & - & - \\
\hline D. Waara & Abrasi & $122^{0} 33^{\prime} 28,25^{\prime \prime}$ & $05^{\circ} 25^{\prime} 6,94^{\prime \prime}$ \\
\hline D. One Waara & Abrasi & $122^{\circ} 34^{\prime} 17,91^{\prime \prime}$ & $05^{\circ} 25^{\prime} 38,27^{\prime \prime}$ \\
\hline
\end{tabular}


Tabel 3. Bentuk perubahan garis pantai berupa akresi di Kecamatan Lakudo, Kabupaten Buton Tengah pada setiap desa/kelurahan pada Tahun 1998-2018.

\begin{tabular}{|c|c|c|c|}
\hline \multirow{3}{*}{$\begin{array}{c}\text { Desa/Kelurahan } \\
\text { Di Kecamatan } \\
\text { Lakudo }\end{array}$} & \multirow{3}{*}{$\begin{array}{l}\text { Perubahan } \\
\text { Garis Pantai } \\
\text { 1998-2018 }\end{array}$} & \multicolumn{2}{|c|}{ Titik Koordinat Geografi } \\
\hline & & \multicolumn{2}{|c|}{ Akresi } \\
\hline & & $\mathbf{X}$ & $\mathbf{Y}$ \\
\hline D. Lolibu & Akresi & $122^{0} 29^{\prime} 35,31^{\prime \prime}$ & $05^{0} 17^{\prime} 37,29^{\prime \prime}$ \\
\hline D. Wajogu & - & - & - \\
\hline D. Moko & Akresi & $122^{0} 31^{\prime} 3,7^{\prime \prime}$ & $05^{0} 16^{\prime} 29,33^{\prime}$, \\
\hline D. Mone & Akresi & $122^{0} 31^{\prime} 48,91^{\prime \prime}$ & $05^{0} 16^{\prime} 1,03^{\prime}$, \\
\hline D. Teluk Lasongko & Akresi & $122^{0} 32^{\prime} 21,82^{\prime}{ }^{\prime}$ & $05^{0} 15^{\prime} 46,44^{\prime}$, \\
\hline D. Matawine & - & - & - \\
\hline D. Wongko Lakudo & Akresi & $122^{0} 31^{\prime} 29,55^{\prime}$, & $05^{0} 17^{\prime} 32,63^{\prime}$, \\
\hline Kel. Lakudo & Akresi & $122^{0} 31^{\prime} 12,69^{\prime \prime}$ & $05^{0} 18^{\prime} 39,23^{\prime \prime}$ \\
\hline Kel. Gu Timur & Akresi & $122^{0} 32^{\prime} 20,14^{\prime}$ ' & $05^{0} 19^{\prime} 45,12^{\prime}$, \\
\hline D. Nepa Mekar & Akresi & $122^{0} 32^{\prime} 11,97^{\prime \prime}$ & $05^{0} 20^{\prime} 21,86^{\prime}$, \\
\hline Kel. Boneoge & Akresi & $122^{0} 31^{\prime} 50,31^{\prime \prime}$ & $05^{0} 21^{\prime} 48,12^{\prime}$, \\
\hline D. Mandongka & Akresi & $122^{0} 31^{\prime} 2,99^{\prime}$ & $05^{0} 25^{\prime} 1,08^{\prime}$ \\
\hline D. Waara & Akresi & $122^{0} 33^{\prime} 37,86^{\prime \prime}$ & $05^{0} 25^{\prime} 43,04^{\prime \prime}$ \\
\hline D. One Waara & Akresi & $122^{0} 36^{\prime} 0,94^{\prime \prime}$ & $05^{0} 25^{\prime} 38,27^{\prime}$ \\
\hline
\end{tabular}

Tabel 4. Jarak pergeseran perubahan garis pantai di Kecamatan Lakudo, Kabupaten Buton Tengah pada setiap desa/kelurahan selama 20 Tahun (1998-2018).

\begin{tabular}{lcc}
\hline \multirow{2}{*}{ Desa/Kelurahan } & \multicolumn{2}{c}{$\begin{array}{c}\text { Jarak Pergeseran Perubahan Garis Pantai } \\
\text { Selama 20 Tahun (1998-2018) }\end{array}$} \\
\cline { 2 - 3 } & Abrasi (m) & Akresi (m) \\
\hline D. Lolibu & 63 & 43 \\
D. Wajogu & 156 & - \\
D. Moko & 114 & 10 \\
D. Mone & 72 & 78 \\
D. Teluk Lasongko & 75 & 68 \\
D. Matawine & 80 & - \\
Kel. Wongko Lakudo & 140 & 89 \\
Kel. Lakudo & 71 & 89 \\
Kel. Gu Timur & 100 & 66 \\
D. Nepa Mekar & 120 & 30 \\
Kel. Boneoge & 11 & 89 \\
D. Mandongka & - & 102 \\
D. Waara & 98 & 77 \\
D. One Waara & 133 & 99 \\
\hline
\end{tabular}

Tabel 4 menunjukan terdapat 12 daerah/desa yang mengalami perubahan garis pantai berupa abrasi dan 13 daerah/desa yang mengalami akresi. Perubahan garis pantai berupa abrasi yang paling besar terjadi di Desa Wajogu dengan pergeseran sebesar 156 $\mathrm{m}$. Sedangkan perubahan garis pantai berupa akresi yang paling besar terjadi di Desa Mandongka dengan pergeseran sebesar 102 $\mathrm{m}$. Berdasarkan pengamatan lapangan hal tersebut terjadi karena adanya pemanfaatan hutan mangrove yang sudah tidak sesuai dengan kaidah yang berlaku serta adanya penambangan pasir. Selain itu, disebabkan oleh hempasan gelombang, pasut dan perubahan pola arus yang berasal dari dari kapal-kapal yang menyebrang ke Pulau Buton. Hal ini didukung oleh penelitian Dahuri et al., (2001) menyatakan, gelombang yang pecah di daerah pantai merupakan salah satu penyebab utama terjadinya proses erosi dan sedimentasi dipantai.

Laju pergeseran perubahan garis pantai di Kecamatan Lakudo, Kabupaten Buton Tengah pada setiap desa/kelurahan selama 20 tahun (1998-2018), dapat dilihat pada Tabel 5. 
Tabel 5. Laju perubahan garis pantai di Kecamatan Lakudo, Kabupaten Buton Tengah pada setiap desa/kelurahan selama 20 tahun (1998-2018).

\begin{tabular}{lcc}
\hline \multirow{2}{*}{ Desa/Kelurahan } & \multicolumn{2}{c}{$\begin{array}{c}\text { Laju Perubahan Garis Pantai Selama 20 Tahun } \\
\text { (1998-2018) }\end{array}$} \\
\cline { 2 - 3 } & Abrasi (m/thn) & Akresi (m)/thn \\
\hline D. Lolibu & 3.15 & 2.15 \\
D. Wajogu & 7.80 & - \\
D. Moko & 5.70 & 0.50 \\
D. Mone & 3.60 & 3.90 \\
D. Teluk Lasongko & 3.75 & 3.40 \\
D. Matawine & 4.00 & - \\
Kel. Wongko Lakudo & 7 & 4.45 \\
Kel. Lakudo & 3.55 & 4.45 \\
Kel. Gu Timur & 5.00 & 3.30 \\
D. Nepa Mekar & 6 & 1.50 \\
Kel. Boneoge & 0.55 & 4.45 \\
D. Mandongka & - & 5.10 \\
D. Waara & 4.90 & 3.85 \\
D. One Waara & 6.65 & 4.95 \\
\hline
\end{tabular}

Laju perubahan garis pantai di Kecamatan Lakudo, kabupaten Buton Tengah selama 20 Tahun yang mengalami abrasi berkisar antara $0.55-7.80 \mathrm{~m} / \mathrm{tahun}$ dan akresi berkisar antara $0.50-5.10 \mathrm{~m} / \mathrm{thn}$ (Tabel 5). Hal tersebut didukung oleh Pragoyo (2015) dalam penelitiannya bahwa, nilai laju abrasi di Kabupaten Kendal terlihat bahwa pada periode pertama dan kedua memiliki nilai hampir sama (40.3 dan $40.8 \mathrm{~m} / \mathrm{thn})$ dan mengalami penurunan pada periode ketiga $(16.4 \mathrm{~m} / \mathrm{thn})$. Luas wilayah dengan laju abrasi terbesar pada periode pertama yaitu Kota Kendal dan disusul oleh Kangkung dan Rowosari. Sedangkan laju penambahan daratan meningkat pada periode kedua dan mengalami penurunan pada periode ketiga dengan laju berkisar $20.1 \mathrm{~m} / \mathrm{thn}$.

Laju perubahan garis pantai berupa abrasi terendah terjadi di Kelurahan Boneoge sebesar $0.55 \mathrm{~m} /$ thn dan abrasi tertinggi terjadi di Desa Wajogu sebesar $7.80 \mathrm{~m} / \mathrm{thn}$ (Tabel 5). Hal ini didukung oleh penelitian Ayu (2015) bahwa, di Lancang Besar abrasi mengalami peningkatan tiap tahunnya sekitar 2.26-5.98 $\mathrm{m} / \mathrm{thn}$ dikarenakan cenderung mengalami arus susur pantai (longshore current) yang membawa material ke arah selatan Lancang Besar. Sedangkan abrasi terjadi di Lancang Kecil mengalami peningkatan sekitar 0.94 sampai $3.34 \mathrm{~m} / \mathrm{thn}$. Abrasi yang terjadi di Lancang Kecil sebagian besar disebabkan oleh alam, dikarenakan tidak ada aktivitas manusia yang mempengaruhi di lokasi tersebut. Sedimen terangkut oleh longshore current mengakibatkan terjadinya pendangkalan pada beberapa bagian di Lancang Kecil.

Laju perubahan garis pantai berupa akresi terendah terjadi di Desa Moko sebesar $0.50 \mathrm{~m} / \mathrm{thn}$ dan abrasi tertinggi terjadi di Desa Mandongka sebesar $5.10 \mathrm{~m} / \mathrm{thn}$ (Tabel 5). Hal ini didukung oleh penelitian Jaya et al., (2017) bahwa, laju perubahan garis pantai di Desa Keramas keseluruhan transek mengalami akresi. Keseluruhan transek di Desa Keramas berjumlah 20 dengan laju akresi tertinggi terjadi pada transek 2 sebesar $5.3642 \mathrm{~m} /$ thn sedangkan laju akresi terendah terjadi pada transek 17 sebesar $1.30575 \mathrm{~m} /$ thn.

Secara umum, perubahan garis pantai yang terjadi di Kecamatan Lakudo, Kabupaten Buton Tengah selama kurung waktu 20 tahun (1998-2018) yang berupa abrasi sekaligus akresi yaitu terjadi pada Desa Lolibu, Mone, Wongko Lakudo, Lakudo, Nepa Mekar, Boneoge, Waara, dan One Waara. Perubahan garis pantai yang terjadi berupa abrasi yaitu terjadi pada Desa Wajogu, Moko dan Mandongka. Perubahan garis pantai yang terjadi berupa akresi yaitu terjadi pada Desa Teluk Lasongko, Matawine dan Kelurahan Gu Timur (Tabel 2 dan 3). Hal tersebut didukung oleh penelitian Cahyono et al., (2017) menyatakan, hasil interpretasi citra menunjukkan bahwa terjadi perubahan garis pantai di Kabupaten Kulonprogo selama periode tahun 1999, 2002, 2013, dan 2016. Perubahan garis pantai yang terjadi sangat bervariasi meliputi kejadian abrasi dan juga akresi. Pengukuran perubahan garis pantai 
dilakukan pada delapan titik dengan rincian setiap kecamatan terdapat dua titik yang diukur. Dua titik di setiap kecamatan meliputi satu titik untuk abrasi terbesar dan satu titik untuk akresi terbesar.

\section{Simpulan}

Berdasarkan hasil dan pembahasan pada penelitian tersebut, maka dapat disimpulkan bahwa:

1. Perubahan garis pantai yang terjadi di wilayah Pesisir Kecamatan Lakudo, Kabupaten Buton Tengah berdasarkan data Citra Landsat 5 TM Tahun 1998, Citra Landsat +ETM 7 Tahun 2001 dan 2010 dengan data Citra Landsat 8 OLI Tahun 2018 terdapat 12 daerah/desa yang mengalami perubahan garis pantai berupa abrasi dan 13 daerah/desa yang mengalami akresi. Perubahan garis pantai berupa abrasi yang paling besar terjadi di Desa Wajogu dengan pergeseran sebesar $156 \mathrm{~m}$ dan abrasi terjadi di Kelurahan Boneoge dengan pergeseran sebesar $11 \mathrm{~m}$. Sedangkan perubahan garis pantai berupa akresi yang paling besar terjadi di Desa Mandongka dengan pergeseran sebesar $102 \mathrm{~m}$ dan akresi terjadi di Desa Moko dengan pergeseran sebesar $10 \mathrm{~m}$.

2. Laju Perubahan garis pantai yang terjadi di wilayah Pesisir Kecamatan Lakudo, Kabupaten Buton Tengah berdasarkan data Citra Landsat 5 TM Tahun 1998, Citra Landsat +ETM 7 Tahun 2001 dan 2010 dengan data Citra Landsat 8 OLI Tahun 2018 selama 20 Tahun dengan laju perubahan garis pantai yang berupa abrasi berkisar antara 0.55-7.80 m/thn sedangkan perubahan garis pantai berupa akresi berkisar antara $0.50-5.10 \mathrm{~m} / \mathrm{thn}$

\section{Daftar Pustaka}

Arief, M., Winarso, G., dan Prayogo, T. 2011. Kajian perubahan garis pantai Menggunakan Data satelit Landsat di kabupaten kendal. Jurnal penginderaan jauh. 71-80.

Arpakul, R.K., Afu, L. O. A. dan Amadhan, T. 2017. Studi Perubahan Garis Pantai Menggunakan Pendekataan Penginderaan Jauh Di Wilayah Pesisir Kecamatan Lakudo Kabupaten Buton Tengah. Sapa Laut. Fakultas Perikanan dan Ilmu Kelautan. Universitas Halu Oleo. Kendari. Vol. 2 (3) : 79-87.
Ayu, C. P. M. 2015. Perubahan Garis Pantai Pulau Lancang Kepulauan Seribu, Dki Jakarta Menggunakan Citra Satelit. Departemen Ilmu Dan Teknologi Kelautan Fakultas Perikanan Dan Ilmu Kelautan Institut Pertanian Bogor. 5790.

Cahyono, H., Retno, Th. W., Musrifah., dan Maulana, E. 2017. Analisis Perubahan Garis Pantai dengan Menggunakan Data Citra Landsat di Pesisir Kabupaten Kulonprogo. Badan Informasi Geospasial, Bogor. Hal 1-15.

Dahuri, R., Rais, Y., Putra, S. G. Dan Sitepu, M. J. 2001. Pengelolaan Sumberdaya Wilayah Pesisir dan Lautan Secara Terpadu. PT. Pradnya Paramita, Jakarta. 234 hal.

Halim, Halili, dan Afu, L. O. A. 2016. Studi Perubahan Garis Pantai Dengan Pendekatan Penginderaan Jauh di Wilayah Pesisir Kecamatan Soropia. Sapa Laut. Fakultas Perikanan dan Ilmu Kelautan. Universitas Halu Oleo. Kendari. 1 (1) : 24-31.

Jaya, I. N. N., I Wayan dan Gede A. K. 2017. Studi Laju Perubahan Garis Pantai di Pesisir Tenggara Bali Menggunakan Citra Satelit Landsat (Studi Kasus Kabupaten Gianyar dan Klungkung). Journal of Marine and Aquatic Sciences 3(2), 204-214

Kalay D. E., Nurjaya I. W. dan Natih N. M. N. 2011. Perubahan Garis Pantai di sepan jang Pesisir Pantai Indramayu. Jurnal Ichthyos. 10 (2) : 111 - 117.

Lubis, D. P., Mbina, P., dan. Ali, N. S. 2012. Analisis Perubahan Garis Pantai Dengan Menggunakan Citra Penginderaan Jauh. Jurusan Pendidikan Geografi Fakultas Ilmu Sosial Universitas Negeri Medan.jurnal geografi. 21-31.

Prayogo, T. 2015. Analisis Pola Perubahan Garis Pantai Pesisir Semarang dan Sekitarnya Berdasarkan Citra Satelit Landsat Mulitemporal. Bidang Sumber Daya Wilayah Pesisir dan Laut, Pusat Pemanfaatan Penginderaan Jauh. Hal. 753-763.

Shuhendry. 2004. Abrasi Pantai Di Wilayah Pesisir Kota Bengkulu (Analisis Faktor Penyebab dan Konsep Penanggulanganya). Universitas Diponegor. Semarang. $1-45$. 